\title{
Adherence to dietary recommendations by children and adolescents during steroid therapy in acute lymphoblastic leukemia
}

\author{
Przestrzeganie zaleceń dietetycznych przez dzieci i młodzież podczas sterydoterapii w leczeniu ostrej \\ białaczki limfoblastycznej
}

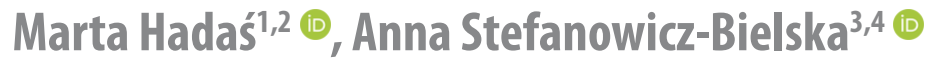

\begin{abstract}
'Clinic of Paediatrics, Haematology and Oncology, The University Clinical Centre in Gdansk/ Klinika Pediatrii, Hematologii i Onkologii, Uniwersyteckie Centrum Kliniczne w Gdańsku ${ }^{2}$ student of Supplementary Master of Science in Nursing program, Faculty of Health Sciences with Institute of Maritime and Tropical Medicine, Medical University of Gdansk/ studentka Magisterskich Studiów Uzupełniających, kierunek Pielęgniarstwo, Wydział Nauk o Zdrowiu z Instytutem Medycyny Morskiej i Tropikalnej, Gdański Uniwersytet Medyczny ${ }^{3}$ Laboratory of Pediatric Nursing, Department of Internal and Pediatric Nursing, Institute of Nursing and Midwifery, Faculty of Health Sciences with Institute of Maritime and Tropical Medicine, Medical University of Gdansk/ Pracownia Pielęgniarstwa Pediatrycznego, Zakład Pielęgniarstwa Internistyczno-Pediatrycznego, Instytut Pielegniarstwa i Położnictwa, Wydział Nauk o Zdrowiu z Instytutem Medycyny Morskiej i Tropikalnej, Gdański Uniwersytet Medyczny ${ }^{4}$ Polish Federation for Education in Diabetology/Polska Federacja Edukacji w Diabetologii
\end{abstract}

CORRESPONDING AUTHOR/AUTOR DO KORESPONDENCJI:

Anna Stefanowicz-Bielska

Pracownia Pielęgniarstwa Pediatrycznego, Zakład Pielęgniarstwa Internistyczno-Pediatrycznego, Instytut Pielęgniarstwa i Położnictwa, Wydział Nauk o Zdrowiu z Instytutem Medycyny Morskiej i Tropikalnej,

Gdański Uniwersytet Medyczny

ul. Dębinki 7, 80-952 Gdansk

e-mail: ania-stefanowicz@gumed.edu.pl

STRESZCZENIE

Słowa kluczowe:

PRZESTRZEGANIE ZALECEN DIETETYCZNYCH PRZZZZ DZIECI I MEODZIEZZ PODCZAS STERYODOTERAPII W LECZENIU OSTREJ BIALACZKI LIMFOBLASTYCZNEJ

Cel. Ocena przestrzegania zaleceń dietetycznych przez dzieci i młodzież podczas sterydoterapii w leczeniu ostrej białaczki limfoblastycznej (ang. acutelymphoblastic leukemia, ALL).

Materiał i metody. Badania przeprowadzono wśród rodziców dzieci z ALL w wieku od 1 do 17 lat leczonych w Klinice Pediatrii, Hematologii i Onkologii Uniwersyteckiego Centrum Klinicznego w Gdańsku. W pracy zastosowano metodę sondażu diagnostycznego, techniką ankietowania. Narzędziem badawczym był anonimowy kwestionariusz ankiety własnej konstrukcji.

Wyniki. W badaniu uczestniczyło 16 rodziców (44,4\%) dzieci płci żeńskiej i 20 rodziców (55,6\%) dzieci płci męskiej. U większości dzieci stwierdzono prawidłową masę ciała 22/36 dzieci. U 15/36 dzieci występowało nadciśnienie tętnicze 1. stopnia, zaś u 6/36 stwierdzono nadciśnienie tętnicze 2. stopnia. U 31/36 dzieci poziom glikemii wynosił 70-180 mg\%. 22/36 badanych dzieci stosowało dietę o niskim indeksie glikemicznym. Aż 29/36 rodziców dzieci i młodzieży z ALL przestrzegało diety zaleconej przez lekarza.

Wnioski. 1) Większoś́ dzieci z ALL podczas sterydoterapii ma prawidłową masę ciała. 2) Dzieci z ALL podczas sterydoterapii są obciążone nadciśnieniem tętniczym. 3)Większość rodziców lub opiekunów prawnych dzieci i młodzieży z ALL stosowała się do zaleceń dietetycznych podczas sterydoterapii.

dieta, sterydy, ostra białaczka limfoblastyczna, dziecko

ABSTRACT

ADHERENCE TO DIETARY RECOMMENDATIONS BY CHILDREN AND ADOLESCENTS DURING STEROID THERAPY IN ACUTE LYMPHOBLASTIC LEUKEMIA

Aim. Assessment of adherence to dietary recommendations by children and adolescents during steroid therapy in the treatment of acute lymphoblastic leukemia (ALL).

Material and methods. The study was conducted among parents of children with ALL, aged from 1 to 17 years, treated at the Department of Paediatrics, Hematology and Oncology of the University Clinical Centre in Gdańsk. The paper uses the method of a diagnostic survey, the questionnaire technique. The research tool was an anonymous self-constructed questionnaire.

Results. The study included 16 parents (44.4\%) of female children and 20 parents (55.6\%) of male children. Normal body weight was found in most of the children (22/36 children). Grade 1 hypertension was found in 15/36 children and grade 2 hypertension in 6/36. In 31/36 children, the blood glucose level was $70-180 \mathrm{mg} \%$. The number of $22 / 36$ examined children used a diet with a low glycemic index. As many as 29/36 parents of children and adolescents with ALL followed the diet recommended by a doctor.

Conclusions. 1) Most children with ALL have normal body weight during steroid therapy. 2) Children with ALL are subject to arterial hypertension during steroid therapy. 3) Most parents or legal guardians of children and adolescents with ALL adhered to dietary recommendations during steroid therapy. 


\section{INTRODUCTION}

Acute lymphoblastic leukemia (ALL) is the most common cancer among children and young people, representing about $30 \%$ of all cancers. The peak incidence of ALL in children is at the age of 2-6. The incidence decreases with age. It is a heterogeneous neoplastic disease $[1,2,3]$.

In the case of diagnosis of ALL in a pediatric patient, glucocorticosteroids are drugs of great importance in therapy. They are one of the basic drugs used in the treatment of ALL [4]. Corticosteroid therapy may increase appetite, especially for foods rich in carbohydrates and salt, and contribute to excessive weight gain in children treated with ALL. Maintaining a proper diet with a low glycemic index may be difficult $[5,6]$.

Treatment with glucocorticosteroids often causes an increase in postprandial glucose levels, insulin resistance, diabetes mellitus, hyperlipidemia, obesity, hypertension and cardiovascular diseases $[7,8]$.

\section{AIM}

The aim of the study is to assess the adherence to dietary recommendations by children and adolescents during steroid therapy in the treatment of acute lymphoblastic leukemia.

\section{MATERIAL AND METHODS}

The study was conducted among parents of children with ALL, aged from 1 to 17 years, treated at the Department of Paediatrics, Hematology and Oncology of the University Clinical Center in Gdańsk from January to May 2019.

The paper uses the method of a diagnostic survey, the questionnaire technique. The research tool was an anonymous self-constructed questionnaire, which consisted of 41 closed questions.

Anthropometric measurements were performed on each child.

When diagnosing eating disorders, the current standards for the assessment of anthropometric parameters for children were used, recommending the diagnosis of overweight and obesity on the basis of the $85^{\text {th }}$ and $95^{\text {th }}$ percentiles of BMI (Body Mass Index) $[9,10]$.

Blood pressure values were measured three times in each child using the oscillometric method [11]. Mean arterial blood pressure values were calculated and related to the blood pressure percentile values for sex, age and height of the American child population [11].

The study was approved by the Independent Bioethics Committee for Scientific Research at the Medical University of Gdańsk (NKBBN/22/2019).

All calculations were performed using Excel 2013 spreadsheet.

\section{RESULTS}

The study included 16 parents $(44.4 \%)$ of female children and 20 parents (55.6\%) of male children aged from 1 to 17 (median age of children 7.06 years).

The median weight and body length ranges of the studied children were $27.17(7 \div 71) \mathrm{kg}$ and $118.64(65 \div 177)$ $\mathrm{cm}$, respectively. The median duration of treatment is $11.22(1 \div 54)$ months.

The number of $16 / 36$ mothers and $18 / 36$ fathers were 31-40 years old, while $17 / 36$ mothers and 16/36 fathers had secondary education and 20/36 parents lived in rural areas. As many as 15/36 mothers and 34/36 fathers were economically active (Tab. 1).

Normal weight was found in $22 / 36$ children, $3 / 36$ children were underweight. Only $2 / 36$ children were overweight, and obesity was diagnosed in $8 / 36$ children (Tab. 1-3).

As many as $15 / 36$ children had grade 1 hypertension, and $6 / 36$ children had grade 2 hypertension (Tab. 1 ).

During treatment with steroids, all children underwent regular blood glucose tests with a blood glucose meter.

Only $1 / 36$ of the children had a blood glucose level below $70 \mathrm{mg} \%$, in $31 / 36$ children, blood glucose levels were $70-180 \mathrm{mg} \%$, and the blood glucose level above 180 $\mathrm{mg} \%$ was found only in $4 / 36$ children (Tab. 1).

Most of the studied children followed a low glycemic diet and an easily digestible diet (22/36) and took vitamin preparations (15/36) (Tab. 2).

During steroid therapy, only $11 / 36$ children took nutritional supplements such as nutririnks, 9/36 ate whole grain and wholemeal bread, 16/36 - red meat, 13/36 sweets, 7/36 drank sugary drinks (Tab. 2).

As many as $28 / 36$ children consumed milk and its products, $16 / 36$ - wheat bread, $35 / 36$ - poultry meat, $31 / 36$ - vegetables, 28/36 - fruits, 23/36 - products containing simple sugars (Tab. 2).

Most parents of children with ALL cook meals for their children (32/36) and follow dietary recommendations while the child is at home (30/35) (Tab. 2). As many as 29/36 parents of children and adolescents with ALL followed the diet prescribed by a doctor (Tab. 2).

The use of glucocorticosteroids in children and adolescents is associated with the occurrence of many organ and systemic complications as well as metabolic disorders [12].

The study by Banecka et al. showed that the use of glucocorticosteroids significantly increases the level of carbohydrate disorders. During the occurrence of disorders, the only effective and safe method of treatment was the administration of insulin preparations and a diabetic diet [13].

In the authors' own research, in the case of excessively high blood glucose levels, most patients used restrictions on food consumption and additional exercise.

The pathogenesis of diabetes mellitus in children with ALL under oncological treatment undergoing steroid therapy and chemotherapy is complex. Decreased insulin production, decreased expression of insulin receptors, and lower affinity of insulin to insulin receptors (insulin resistance) may be caused by the use of asparaginase and corticosteroids during treatment [14]. 


\section{Adherence to dietary recommendations by children and adolescents in acute lymphoblastic leukemia}

Tab. 1. Characteristics of the studied group

\begin{tabular}{|c|c|c|}
\hline & $\begin{array}{c}\mathbf{N} \\
\text { (number) }\end{array}$ & $\%$ \\
\hline \multicolumn{3}{|l|}{ nutritional status of children with ALL } \\
\hline underweight - body max index $(\mathrm{BMI})<5$. percentiles & 3 & 8.6 \\
\hline normal body weight - body max index (BMI) 5. - 85. percentiles & 22 & 62.9 \\
\hline $\begin{array}{l}\text { overweight - body max index }(\mathrm{BMI}) \geq 85 \text {. percentiles } \\
\text { and }<95 \text {. percentiles }\end{array}$ & 2 & 5.7 \\
\hline obesity - body max index $(\mathrm{BMI}) \geq 95$. percentiles & 8 & 22.9 \\
\hline \multicolumn{3}{|l|}{ blood pressure in children and adolescents with ALL } \\
\hline normal blood pressure $-<90$. percentiles & 13 & 36.1 \\
\hline $\begin{array}{l}\text { normal high blood pressure }-90 \text {. }-95 \text {. percentiles } \\
\text { or } \geq 120 / 80 \mathrm{~mm} \mathrm{Hg}\end{array}$ & 2 & 5.6 \\
\hline grade 1 hypertension $-\geq 95$. -99 . percentiles $+5 \mathrm{~mm} \mathrm{Hg}$ & 15 & 41.7 \\
\hline grade 2 hypertension $-\geq 99$. percentiles $+5 \mathrm{~mm} \mathrm{Hg}$ & 6 & 16.7 \\
\hline \multicolumn{3}{|c|}{ blood glucose levels during steroid therapy in children with ALL } \\
\hline below $70 \mathrm{mg} \%$ & 1 & 2.8 \\
\hline $70-180 \mathrm{mg} \%$ & 31 & 86.1 \\
\hline over $180 \mathrm{mg} \%$ & 4 & 11.1 \\
\hline \multicolumn{3}{|l|}{ what was used in the case of too high blood glucose levels } \\
\hline restriction of food consumption & 24 & 43.6 \\
\hline additional exercise, e.g. walking, riding an exercise bike & 24 & 43.6 \\
\hline use of insulin preparations & 7 & 12.7 \\
\hline \multicolumn{3}{|l|}{ increased appetite and weight gain } \\
\hline yes & 31 & 86.1 \\
\hline no & 5 & 13.9 \\
\hline \multicolumn{3}{|l|}{ mother's age (years) } \\
\hline under 25 & 1 & 2.8 \\
\hline $25-30$ & 10 & 27.8 \\
\hline $31-40$ & 16 & 44.4 \\
\hline $41-50$ & 9 & 25.0 \\
\hline over 50 & 0 & 0 \\
\hline \multicolumn{3}{|l|}{ father's age (years) } \\
\hline under 25 & 0 & 0 \\
\hline $25-30$ & 6 & 16.7 \\
\hline $31-40$ & 18 & 50.0 \\
\hline $41-50$ & 7 & 19.4 \\
\hline over 50 & 5 & 13.9 \\
\hline \multicolumn{3}{|l|}{ residence } \\
\hline rural & 20 & 55.6 \\
\hline urban & 16 & 44.4 \\
\hline
\end{tabular}

mother's education

\begin{tabular}{|l|c|c|}
\hline primary & 1 & 2.8 \\
\hline secondary & 17 & 47.2 \\
\hline vocational & 5 & 13.9 \\
\hline higher & 13 & 36.1 \\
\hline
\end{tabular}

father's education

\begin{tabular}{|l|c|c|}
\hline primary & 3 & 8.3 \\
\hline secondary & 16 & 44.4 \\
\hline vocational & 9 & 25.0 \\
\hline higher & 8 & 22.2 \\
\hline
\end{tabular}

mother's professional activity

\begin{tabular}{|l|c|c|}
\hline working & 15 & 41.7 \\
\hline non-working & 21 & 58.3 \\
\hline father's professional activity & 34 & 94.4 \\
\hline working & 2 & 5.6 \\
\hline non-working
\end{tabular}

In their study, Lowas et al. noted disturbances in carbohydrate metabolism, which were additionally caused by asparaginase used in therapeutic protocols. As many as $20 \%$ of respondents had a transient hyperglycemia [15].

In the study by Aisyi et al. only $5.2 \%$ of the respondents were diagnosed with hyperglycemia caused by dexamethasone in combination with L-asparaginase [16].

In the study conducted by the authors, only in $1 / 36$ of the children the blood glucose level was below $70 \mathrm{mg} \%$, and the glucose concentration above $180 \mathrm{mg} \%$ was found only in $4 / 36$ children. The remaining children had normal blood glucose levels. These results may be related to the fact that $80.6 \%$ of respondents stated that their children follow the diet.

Obesity is a common health problem in children with ALL. It is the result of excessive energy consumption and reduced energy expenditure [17].

In a study by Esbenshade et al. and Jansen et al., obesity and arterial hypertension were reported in children diagnosed with acute lymphoblastic leukemia during treatment with glucocorticosteroids $[8,17]$.

In their studies, Van Dongen-Melman et al. found that obesity in children with ALL was a late side effect of treatment. They showed that the use of glucocorticosteroids had the greatest impact on weight gain in children with leukemia [18].

Iughetii et al. showed that the majority of young people who were treated for ALL suffer from excessive weight gain, central obesity, dyslipidemia and metabolic syndrome [19].

In their studies, Veringa et al. showed that obesity or overweight occurs in $38.2 \%$ of ALL survivors. Prehypertension was diagnosed in $48.5 \%$ of the subjects, and arterial hypertension in $22.1 \%$ [20].

In our study, 13/36 children with ALL had normal blood pressure, 15/36 had grade 1 hypertension, and 6/36 had grade 2 hypertension, whereas normal body weight was found in $22 / 36$ children, underweight in $3 / 36$, overweight in $2 / 36$, and obesity in $8 / 36$ children.

Diet and exercise are one of the few modifiable behaviors that can prevent or delay the onset of obesity-related chronic diseases. Physical activity in children with ALL improves physical and metabolic performance, reduces the risk of physical impairment and improves the quality of life [21].

Reilly et al. and Alias et al. observed reduced physical activity in children withALL. They perform much less physical activity than their healthy peers, both during and after therapy $[6,22]$. Children who have completed their treatment for leukemia should regularly perform physical activity appropriate to their cardiopulmonary and muscular capacity [21].

Children with cancer are more prone to malnutrition and excessive weight gain during treatment [23]. The use of corticosteroids may lead to a higher consumption of high-energy products $[6,17]$.

Li et al. showed that children who survived treatment for ALL consumed high-energy products, poor in micronutrients. Additionally, prednisone and dexamethasone increase the appetite for foods high in carbohydrates and salt. Therefore, the application of the principles of rational nutrition during treatment may reduce body weight gain [5]. 
Marta Hadaś, Anna Stefanowicz-Bielska

Tab. 2. Diet and nutritional education in children and adolescents with ALL

\begin{tabular}{|c|c|c|}
\hline & $N$ (number) & $\%$ \\
\hline \multicolumn{3}{|l|}{ Diet } \\
\hline \multicolumn{3}{|c|}{ consumption of wholemeal bread, whole grain bread } \\
\hline yes & 9 & 25.0 \\
\hline no & 15 & 41.7 \\
\hline I mix whole grain and wheat flour products & 12 & 33.3 \\
\hline \multicolumn{3}{|l|}{ consumption of wheat and corn bread } \\
\hline yes & 16 & 44.4 \\
\hline no & 9 & 25.0 \\
\hline I mix whole grain and wheat flour products & 11 & 30.6 \\
\hline \multicolumn{3}{|l|}{ consumption of milk and milk products } \\
\hline yes & 28 & 77.8 \\
\hline no & 8 & 22.2 \\
\hline \multicolumn{3}{|l|}{ consumption of fish } \\
\hline yes & 18 & 50.0 \\
\hline no & 18 & 50.0 \\
\hline \multicolumn{3}{|c|}{ consumption of red meat (beef, veal, pork, lamb) } \\
\hline yes & 16 & 44.4 \\
\hline no & 20 & 55.6 \\
\hline \multicolumn{3}{|l|}{ consumption of poultry } \\
\hline yes & 35 & 97.2 \\
\hline no & 1 & 2.8 \\
\hline \multicolumn{3}{|l|}{ consumption of vegetables } \\
\hline yes & 31 & 86.1 \\
\hline no & 5 & 13.9 \\
\hline \multicolumn{3}{|l|}{ consumption of fruit } \\
\hline yes & 28 & 77.8 \\
\hline no & 8 & 22.2 \\
\hline
\end{tabular}

consumption of sweets

yes

no

\begin{tabular}{|l|l|}
\hline 13 & 36.1 \\
\hline 23 & 63.9 \\
\hline
\end{tabular}

consumption of sugar-sweetened carbonated beverages, juice, sweet tea yes

no

consumption of ready-made products containing simple carbohydrates, e.g. cereals, fruit yoghurts, ketchup

\begin{tabular}{|l|c|c|}
\hline yes & 23 & 63.9 \\
\hline no & 13 & 36.1 \\
\hline consumption of fast food (chips, pizza, hamburgers hot dogs) \\
\hline yes & 11 & 30.6 \\
\hline no & 25 & 69.4 \\
\hline consumption of dietary supplements & 15 & 39.5 \\
\hline yes, vitamin preparations & 1 & 2.6 \\
\hline yes, cod liver oil & 1 & 2.6 \\
\hline yes, shark liver oil & 8 & 21.1 \\
\hline yes, vitamin supplements containing omega-3 fatty acids & 13 & 34.2 \\
\hline no, the child did not take any dietary supplements & 11 & 30.6 \\
\hline consumption of nutritional supplements, e.g. NutriDrinks \\
\hline yes & 25 & 69.4 \\
\hline no & 23 & 63.9 \\
\hline snacking between meals & 13 & 36.1 \\
\hline yes & \multicolumn{2}{|l}{} \\
\hline no & \multicolumn{2}{|l}{} \\
\hline
\end{tabular}

cd. Tab. 2. Diet and nutritional education in children and adolescents with ALL

\begin{tabular}{|c|c|c|}
\hline & $\mathbf{N}$ (number) & $\%$ \\
\hline Diet & \\
\hline
\end{tabular}

\section{the type of diet prescribed by a doctor}

yes, a dairy-free diet

yes, a gluten-free diet

\begin{tabular}{|l|l|}
\hline 2 & 2.9 \\
\hline 2 & 2.9 \\
\hline
\end{tabular}

yes, a diet with restriction of raw foods

yes, an easily digestible diet

yes, a low-fat diet

yes, a low-glycemic diet

no, the child did not have any specific diet

\begin{tabular}{l|l|}
8 & 11.6 \\
\hline & 31.9
\end{tabular}

following the diet prescribed by a doctor

\begin{tabular}{|l|c|c|}
\hline yes & 29 & 80.6 \\
\hline no & 7 & 19.4 \\
\hline
\end{tabular}

way of preparing meals

cooked

roast

fried

consumption of meals by the child while in hospital

only brought by parents

hospital meals only

\begin{tabular}{l|l|}
22 & 31.9 \\
\hline
\end{tabular}

both

\begin{tabular}{c|c|}
\hline 9 & 13.0 \\
\hline 22 & 31.9 \\
\hline
\end{tabular}

\begin{tabular}{l|l}
4 & 5.8 \\
\hline
\end{tabular}

adherence to dietary recommendations while the child was at home

\begin{tabular}{|l|c|c|}
\hline yes & 30 & 83.3 \\
\hline no & 6 & 16.7 \\
\hline
\end{tabular}

reasons for deviations from the recommended diet

lack of healthy eating habits, consumption of large amounts

of sweets and fast foods before treatment

increased appetite caused by taking steroids

the child's reluctance to eat products with a low glycemic

index

the desire to compensate the child for the difficulties of the

disease

a conviction that diet is of little importance during steroid

treatment

lack of knowledge of the need for a diet

there were no deviations from the diet

\begin{tabular}{|c|c|c|}
\hline ts & 3 & 5.9 \\
\hline & 20 & 39.2 \\
\hline 10 & 19.6 \\
\hline 6 & 11.8 \\
\hline 1 & 2.0 \\
\hline 1 & 2.0 \\
\hline & 10 & 19.6 \\
\hline
\end{tabular}

the number of meals eaten by the child

\begin{tabular}{|l|c|c|}
\hline $3-4$ & 6 & 16.7 \\
\hline $5-6$ & 15 & 41.7 \\
\hline 6 or more & 15 & 41.7 \\
\hline \multicolumn{3}{|c|}{ Nutrition education } \\
\hline information that the child needs to follow a diet \\
\hline yes & 32 & 88.9 \\
\hline no & 4 & 11.1 \\
\hline
\end{tabular}

participation of parents in educational meetings on proper nutrition and the principles of glycemic self-control

\begin{tabular}{|l|l|l|}
\hline yes & 14 & 38.9 \\
\hline no & 22 & 61.1 \\
\hline
\end{tabular}

a person educating about proper nutrition and the principles of glycemic self-control

\begin{tabular}{|l|c|c|}
\hline a doctor & 20 & 31.2 \\
\hline a nurse & 10 & 15.6 \\
\hline a dietitian & 3 & 4.7 \\
\hline a parent of another treated child & 10 & 15.6 \\
\hline I read news from the internet, books, magazines & 10 & 15.6 \\
\hline nobody educated me & 11 & 17.2 \\
\hline
\end{tabular}


In our study, patients had an increased appetite during treatment with glucocorticosteroids, but there was no increased consumption of sweets, fast food or white bread, which are not allowed in the diet. Moreover, treatment with glucocorticoids is an additional risk factor of bacterial and fungal infections in cancer patients.

Studies by Sonabend et al. have shown an association between the occurrence of transient hyperglycemia in children treated for acute lymphoblastic leukemia and an increased risk of bacteremia, as well as necessary additional hospitalizations. Patients with mild hyperglycaemia, 140-199 mg/dL, and hyperglycaemia above $200 \mathrm{mg} / \mathrm{dL}$ in the first year of treatment, had a 4.2 times higher incidence of bacterial or fungal infections compared to children with normal blood glucose levels. These children were more frequently hospitalized due to fever and neutropenia [24].

In the O'Connor's study, 35\% of children with ALL suffered from respiratory tract infections, $11 \%$ from gastrointestinal infections and $11 \%$ from infections of the central nervous system [25].

Similar results were obtained by Weiser et al. Patients with hyperglycemia during induction chemotherapy for
ALL are more likely to develop infections and experience a significant increase in overall mortality as well as the risk of relapse compared to patients without symptoms of hyperglycemia [26].

Given that lifestyle is a modifiable factor, it seems necessary to promote a healthy lifestyle in ALL patients and their families. Attention should be paid to health education conducted during and also after treatment, to minimize the risk of obesity development and health problems resulting from it in children and adults who underwent oncological treatment in childhood.

\section{CONCLUSIONS}

1. Normal body weight is found in most children with ALL during steroid therapy.

2. Children with ALL have high blood pressure during steroid therapy.

3. Most parents or legal guardians of children and adolescents with ALL adhered to dietary recommendations during steroid therapy.

\section{Przestrzeganie zaleceń dietetycznych przez dzieci i młodzież podczas sterydoterapii w leczeniu ostrej białaczki limfoblastycznej}

\section{WPROWADZENIE}

Ostra białaczka limfoblastyczna (ang. acute lymphoblastic leukemia, ALL) jest najczęściej występującym nowotworem wśród dzieci i młodzieży, w u których stanowi około 30\% wszystkich nowotworów. Szczyt zachorowań na ALL u dzieci przypada na 2-6 r.ż.. Częstość zachorowań zmniejsza się wraz z wiekiem. Jest to heterogenna choroba nowotworowa $[1,2,3]$.

$\mathrm{W}$ przypadku rozpoznania ALL u pacjenta pediatrycznego glikokortykosteroidy są lekami o bardzo istotnym znaczeniu w terapii. Stanowią jeden $\mathrm{z}$ podstawowych leków stosowanych w terapii ALL [4].

Terapia kortykosteroidami może powodować zwiększenie łaknienia, zwłaszcza wzrost apetytu na pokarmy bogate $\mathrm{w}$ węglowodany i sól oraz przyczynia się do nadmiernego przyrostu masy ciała u dzieci leczonych na ALL. Utrzymanie prowadzenia prawidłowej diety o niskim indeksie glikemicznym może być utrudnione [5,6].

Leczenie przy użyciu glikokortykosteroidów często powoduje wzrost poziomu glikemii poposiłkowej, insulinooporność, cukrzycę, hiperlipidemię, otyłość, nadciśnienie tętnicze krwi i choroby układu sercowo-naczyniowego $[7,8]$.

\section{CEL PRACY}

Celem pracy jest ocena przestrzegania zaleceń dietetycznych przez dzieci i młodzież podczas sterydoterapii w leczeniu ostrej białaczki limfoblastycznej.

\section{MATERIAŁ I METODY}

Badania przeprowadzono wśród rodziców dzieci z ALL w wieku od 1 do 17 lat leczonych w Klinice Pediatrii, Hematologii i Onkologii Uniwersyteckiego Centrum Klinicznego w Gdańsku od stycznia do maja 2019 roku.

W pracy zastosowano metodę sondażu diagnostycznego, techniką ankietowania. Narzędziem badawczym był anonimowy kwestionariusz ankiety własnej konstrukcji, który składał się z 41 pytań zamkniętych.

Pomiary antropometryczne przeprowadzono u każdego dziecka.

Przy rozpoznawaniu zaburzeń odżywiania stosowano aktualne standardy oceny parametrów antropometrycznych dla dzieci rekomendujące rozpoznawanie nadwagi i otyłości na podstawie 85. i 95. percentyla BMI (Body Mass Index) $[9,10]$.

U każdego dziecka 3-krotnie dokonano pomiaru wartości ciśnień krwi metodą oscylometryczną [11]. Obliczono średnie wartości ciśnień tętniczych krwi, które odniesiono do wartości centylowych ciśnienia tętniczego dla płci, wieku i wzrostu populacji dzieci amerykańskich [11]. 
Marta Hadaś, Anna Stefanowicz-Bielska

Przeprowadzenie badań zostało zatwierdzone przez Niezależną Komisją Bioetyczną ds. Badań Naukowych Gdańskiego Uniwersytetu Medycznego (NKBBN/22/2019).

Wszystkie obliczenia zostały przeprowadzone przy użyciu arkusza kalkulacyjnego Excel 2013.

\section{WYNIKI}

W badaniu uczestniczyło 16 rodziców $(44,4 \%)$ dzieci płci żeńskiej i 20 rodziców (55,6\%) dzieci płci męskiej w wieku od 1 do 17 lat (mediana wieku dzieci 7.06 lat).

Mediany i zakresy masy oraz długości ciała badanych dzieci wynosiły odpowiednio $27.17(7 \div 71) \mathrm{kg}$ i 118.64 $(65 \div 177) \mathrm{cm}$. Mediana czasu leczenia to $11.22(1 \div 54)$ miesięcy.

16/36 matek i 18/36 ojców było w wieku 31-40 lat, 17/36 matek i 16/36 ojców posiadało wykształcenie średnie i 20/36 rodziców zamieszkiwało tereny wiejskie. 15/36 matek i 34/36 ojców było aktywnych zawodowo (tab. 1).

U 22/36 dzieci stwierdzono prawidłową masę ciała, u 3/36 dzieci wystąpiła niedowaga.

Nadwagę rozpoznano jedynie u 2/36 dzieci, a otyłość u 8/36 dzieci (tab. 1).

Aż u 15/36 dzieci występowało nadciśnienie tętnicze 1. stopnia, zaś u 6/36 dzieci stwierdzono nadciśnienie tętnicze 2. stopnia (tab. 1).

Wszystkie badane dzieci podczas leczenia sterydami miały wykonywane regularne pomiary glikemii za pomocą glukometru.

Wyłącznie u 1/36 dziecka zaobserwowano poziom glikemii poniżej $70 \mathrm{mg} \%$, u 31/36 dzieci poziomy glikemii wynosiły 70-180 mg\%, wynik glikemii powyżej $180 \mathrm{mg} \%$ stwierdzono wyłącznie u 4/36 dzieci (tab. 1).

Większość badanych dzieci stosowało dietę o niskim indeksie glikemicznym i dietę lekkostrawną (22/36) oraz spożywało preparaty witaminowe (15/36) (tab. 2).

Podczas sterydoterapii tylko 11/36 dzieci spożywało preparaty odżywcze typu np. Nutridrinki, 9/36 pieczywo pełnoziarniste i razowe, 16/36 mięso czerwone, 13/36 słodycze, $7 / 36$ słodkie napoje (tab. 2 ).

Aż 28/36 dzieci spożywało mleko i jego przetwory, $16 / 36$ pieczywo pszenne 35/36 mięso drobiowe, $31 / 36$ warzywa, $28 / 36$ owoce, $23 / 36$ produkty zawierające cukry proste (tab. 2).

Większość rodziców dzieci z ALL gotuje potrawy dla swoich dzieci (32/36) i przestrzega zaleceń dietetycznych podczas pobytu dziecka w domu (30/35) (tab. 2). Aż 29/36 rodziców dzieci i młodzieży z ALL przestrzegało diety zaleconej przez lekarza (tab. 2).

\section{Tab. 1. Charakterystyka badanej grupy}

\begin{tabular}{|c|c|c|}
\hline & N (licba) & $\%$ \\
\hline \multicolumn{3}{|l|}{ stan odżywienia dzieci z ALL } \\
\hline niedowaga - wskaźnik masy ciała $(\mathrm{BMI})<5$. percentyl & 3 & 8,6 \\
\hline $\begin{array}{l}\text { prawidłowa masa ciała - wskaźnik masy ciała (BMI) 5. - } 85 . \\
\text { percentyl }\end{array}$ & 22 & 62,9 \\
\hline $\begin{array}{l}\text { nadwaga - wskaźnik masy ciała }(\mathrm{BMI}) \geq 85 \text {. percentyl } \mathrm{i}<95 \text {. } \\
\text { percentyl }\end{array}$ & 2 & 5,7 \\
\hline otyłość - wskaźnik masy ciała $(B M I) \geq 95$. percentyl & 8 & 22,9 \\
\hline \multicolumn{3}{|l|}{ ciśnienie tętnicze krwi u dzieci i młodzieży z ALL } \\
\hline ciśnienie tętnicze prawidłowe $-<90$. percentyl & 13 & 36,1 \\
\hline ciśnienie tętnicze prawidłowe wysokie -90 . - 95. percentyl & 2 & 5,6 \\
\hline $\mathrm{lub} \geq 120 / 80 \mathrm{~mm} \mathrm{Hg}$ & 15 & 41,7 \\
\hline $\begin{array}{l}\text { nadciśnienie tętnicze 1, stopnia - } \geq 95 \text { - 99. percentyl + } 5 \\
\mathrm{~mm} \mathrm{Hg}\end{array}$ & 6 & 16,7 \\
\hline \multicolumn{3}{|l|}{ poziomy glikemii podczas sterydoterapii u dzieci z ALL } \\
\hline poniżej $70 \mathrm{mg} \%$ & 1 & 2,8 \\
\hline $70-180 \mathrm{mg} \%$ & 31 & 86,1 \\
\hline powyżej 180 mg\% & 4 & 11,1 \\
\hline \multicolumn{3}{|l|}{ w przypadku zbyt wysokich poziomów glikemii stosowano } \\
\hline ograniczenie spożywania pokarmu & 24 & 43,6 \\
\hline dodatkowy ruch np. spacer, jazda na rowerku stacjonarnym & 24 & 43,6 \\
\hline & & \\
\hline
\end{tabular}

występowanie wzmożonego apetytu i przybieranie na masie ciała

\begin{tabular}{|l|c|c|}
\hline tak & 31 & 86,1 \\
\hline nie & 5 & 13,9 \\
\hline
\end{tabular}

\section{wiek matki}

\begin{tabular}{|l|l|l|}
\hline poniżej 25 lat & 1 & 2,8 \\
\hline $25-30 l a t$
\end{tabular}

\begin{tabular}{|l|c|c|}
\hline 25 - 30 lat & 10 & 27,8 \\
\hline $31-40$ lat
\end{tabular}

\begin{tabular}{|l|c|c|}
\hline $31-40$ lat & 16 & 44,4 \\
\hline $41-50$ lat
\end{tabular}

\begin{tabular}{|l|c|c|}
\hline 41 - 50 lat & 9 & 25,0 \\
\hline powyzej50 lat & 0 & 0 \\
\hline
\end{tabular}

powyżej 50 lat

wiek ojca

\begin{tabular}{|l|c|c|}
\hline poniżej 25 lat & 0 & 0 \\
\hline 25 - 30 lat & 6 & 16,7 \\
\hline 31 - 40 lat & 18 & 50,0 \\
\hline 41 - 50 lat & 7 & 19,4 \\
\hline powyżej50 lat & 5 & 13,9 \\
\hline miejsce zamieszkania & 20 & 55,6 \\
\hline wieś & 16 & 44,4 \\
\hline miasto & \multicolumn{3}{|l}{} \\
\hline
\end{tabular}

wykształcenie matki dziecka

\begin{tabular}{|l|c|c|}
\hline podstawowe & 1 & 2,8 \\
\hline średnie & 17 & 47,2 \\
\hline zasadnicze zawodowe & 5 & 13,9 \\
\hline wyższe & 13 & 36,1 \\
\hline
\end{tabular}

\section{wykształcenie ojca dziecka}

\begin{tabular}{|l|c|c|}
\hline podstawowe & 3 & 8,3 \\
\hline średnie & 16 & 44,4 \\
\hline zasadnicze zawodowe & 9 & 25,0 \\
\hline wyższe & 8 & 22,2 \\
\hline
\end{tabular}

\begin{tabular}{|l|c|c|}
\hline aktywność zawodowa matek & 15 & 41,7 \\
\hline pracuje & 21 & 58,3 \\
\hline nie pracuje & 34 & 94,4 \\
\hline aktywność zawodowa ojców & 2 & 5,6 \\
\hline pracuje &
\end{tabular}




\section{Przestrzeganie zaleceń dietetycznych przez dzieci i młodzież z ostrą białaczką limfoblastyczna}

Tab. 2. Dieta u dzieci i młodzieży z ALL i edukacja żywieniowa

\begin{tabular}{|c|c|c|}
\hline & N (licza) & $\%$ \\
\hline \multicolumn{3}{|l|}{ Dieta } \\
\hline \multicolumn{3}{|c|}{ spożywanie pieczywa pełnoziarnistego, pieczywa razowego } \\
\hline tak & 9 & 25,0 \\
\hline nie & 15 & 41,7 \\
\hline $\begin{array}{l}\text { mieszam produkty pełnoziarniste oraz produkty z mąki } \\
\text { pszennej }\end{array}$ & 12 & 33,3 \\
\hline \multicolumn{3}{|l|}{ spożywanie pieczywa pszennego, kukurydzianego } \\
\hline tak & 16 & 44,4 \\
\hline nie & 9 & 25,0 \\
\hline $\begin{array}{l}\text { mieszam produkty pełnoziarniste oraz produkty z mąki } \\
\text { pszennej }\end{array}$ & 11 & 30,6 \\
\hline \multicolumn{3}{|l|}{ spożywanie mleka i jego przetworów } \\
\hline tak & 28 & 77,8 \\
\hline nie & 8 & 22,2 \\
\hline \multicolumn{3}{|l|}{ spożywanie ryb } \\
\hline tak & 18 & 50,0 \\
\hline nie & 18 & 50,0 \\
\hline
\end{tabular}

spożywanie mięsa czerwonego (wołowina, cielęcina, wieprzowina,

baranina)

\begin{tabular}{|c|c|c|}
\hline tak & 16 & 44,4 \\
\hline nie & 20 & 55,6 \\
\hline \multicolumn{3}{|c|}{ spożywanie mięsa drobiowego } \\
\hline tak & 35 & 97,2 \\
\hline nie & 1 & 2,8 \\
\hline \multicolumn{3}{|c|}{ spożywanie warzyw } \\
\hline tak & 31 & 86,1 \\
\hline nie & 5 & 13,9 \\
\hline \multicolumn{3}{|c|}{ spożywanie owoców } \\
\hline tak & 28 & 77,8 \\
\hline nie & 8 & 22,2 \\
\hline \multicolumn{3}{|c|}{ spożywanie słodyczy } \\
\hline tak & 13 & 36,1 \\
\hline nie & 23 & 63,9 \\
\hline \multicolumn{3}{|c|}{ spożywanie słodkich napoi gazowanych, soków, słodkiej herbaty } \\
\hline tak & 7 & 19,4 \\
\hline nie & 29 & 80,6 \\
\hline \multicolumn{3}{|c|}{$\begin{array}{l}\text { spożywanie gotowych produktów zawierających węglowodany proste, } \\
\text { np. płatki śniadaniowe, jogurty owocowe, ketchup }\end{array}$} \\
\hline tak & 23 & 63,9 \\
\hline nie & 13 & 36 \\
\hline
\end{tabular}

spożywanie pokarmów typu fast-food (frytki, pizzę, hamburgery, hotdogi)

\begin{tabular}{|c|c|c|}
\hline tak & 11 & 30,6 \\
\hline nie & 25 & 69,4 \\
\hline \multicolumn{3}{|l|}{ spożywanie suplementów diety } \\
\hline tak, preparaty witaminowe & 15 & 39,5 \\
\hline tak, tran & 1 & 2,6 \\
\hline tak, olej z wątroby rekina & 1 & 2,6 \\
\hline $\begin{array}{l}\text { tak, suplementy witaminowe zawierające kwasy tłuszczowe } \\
\text { omega-3 }\end{array}$ & 8 & 21,1 \\
\hline nie, dziecko nie spożywało suplementów diety & 13 & 34,2 \\
\hline \multicolumn{3}{|l|}{ spożywanie preparatów odżywczych np. Nutridrink } \\
\hline tak & 11 & 30,6 \\
\hline nie & 25 & 69,4 \\
\hline \multicolumn{3}{|l|}{ podjadanie między posiłkami } \\
\hline tak & 23 & 63,9 \\
\hline nie & 13 & 36,1 \\
\hline
\end{tabular}

cd. Tab. 2. Dieta u dzieci i młodzieży z ALL i edukacja żywieniowa

\begin{tabular}{|c|c|c|}
\hline & N (liczba) & $\%$ \\
\hline \multicolumn{3}{|l|}{ Dieta } \\
\hline \multicolumn{3}{|l|}{ rodzaj zaleconej diety przez lekarza } \\
\hline tak, dieta bezmleczna & 2 & 2,9 \\
\hline tak, dieta bezglutenowa & 2 & 2,9 \\
\hline tak, dieta z ograniczeniem surowych produktów & 8 & 11,6 \\
\hline tak, dieta lekkostrawna & 22 & 31,9 \\
\hline tak, dieta z ograniczeniem tłuszczu & 9 & 13,0 \\
\hline tak, dieta o niskim indeksie glikemicznym & 22 & 31,9 \\
\hline nie, dziecko nie miało określonej diety & 4 & 5,8 \\
\hline \multicolumn{3}{|l|}{ przestrzeganie diety zaleconej przez lekarza } \\
\hline tak & 29 & 80,6 \\
\hline nie & 7 & 19,4 \\
\hline \multicolumn{3}{|l|}{ sposób przygotowywania potraw } \\
\hline gotowane & 32 & 88,9 \\
\hline pieczone & 1 & 2,8 \\
\hline smażone & 3 & 8,3 \\
\hline
\end{tabular}

spożywanie posiłków przez dziecko podczas pobytu w szpitalu

tylko przynoszone przez rodziców

tylko szpitalne

\begin{tabular}{|l|c|l} 
szpitalne i przynoszone przez rodziców & 18 & 50,0 \\
\hline
\end{tabular}

\begin{tabular}{l|l}
17 & 47,2 \\
\hline
\end{tabular} stosowanie się do zaleceń dietetycznych podczas pobytu dziecka w domu \begin{tabular}{|l|c|l|}
\hline tak & 30 & 83,3 \\
\hline nie & 6 & 16,7 \\
\hline
\end{tabular}

przyczyny odstępstw od zaleconej diety

\begin{tabular}{|l|l|l|}
\hline brak zdrowych nawyków żywieniowych, spożywanie dużej & 3 & 5,9
\end{tabular} \begin{tabular}{|l|c|c|}
\hline ilości słodyczy, fast-foodów przed rozpoczęciem leczenia & 3 & 5,9 \\
\hline wzmożony apetyt spowodowany przyjmowaniem sterydów & 20 & 39,2 \\
\hline
\end{tabular} \begin{tabular}{l|ll} 
wzmożony apetyt spowodowany przyjmowaniem sterydów & 20 & 39,2 \\
\hline niechęć dziecka do spożywania produktów o niskim indeksie &
\end{tabular} \begin{tabular}{|l|l|l|}
\hline glikemicznym & 10 & 19,6 \\
\hline
\end{tabular} chęć wynagrodzenia dziecku trudności choroby uważanie, że dieta ma małe znaczenie w trakcie leczenia sterydami

brak wiedzy na temat konieczności stosowania diety nie stosowano odstępstw od diety

\begin{tabular}{c|c|}
\hline 6 & 11,8 \\
\hline 1 & 2,0 \\
\hline 1 & 2,0 \\
\hline 10 & 19,6 \\
\hline
\end{tabular}

ilość spożywanych przez dziecko posiłków

\begin{tabular}{|l|c|c|}
\hline $3-4$ & 6 & 16,7 \\
\hline $5-6$ & 15 & 41,7 \\
\hline 6 i więcej & 15 & 41,7 \\
\hline
\end{tabular}

6 i więcej

Edukacja żywieniowa

informacja o konieczności przestrzegania diety u dziecka

\begin{tabular}{|l|c|c|}
\hline tak & 32 & 88,9 \\
\hline nie & 4 & 11,1 \\
\hline
\end{tabular}

uczestnictwo rodziców w spotkaniach edukacyjnych na temat prawidłowego odżywiania i zasad samokontroli glikemii

\begin{tabular}{|c|c|c|}
\hline tak & 14 & 38,9 \\
\hline nie & 22 & 61,1 \\
\hline \multicolumn{3}{|c|}{$\begin{array}{l}\text { osoba prowadząca edukację na temat prawidłowego odżywiania i zasad } \\
\text { samokontroli glikemii }\end{array}$} \\
\hline lekarz & 20 & 31,2 \\
\hline pielęgniarka & 10 & 15,6 \\
\hline dietetyk & 3 & 4,7 \\
\hline rodzic innego leczonego dziecka & 10 & 15,6 \\
\hline $\begin{array}{l}\text { czytałem/łam wiadomości zawarte w internecie, książkach, } \\
\text { czasopismach }\end{array}$ & 10 & 15,6 \\
\hline nikt mnie nie edukował & 11 & 17,2 \\
\hline
\end{tabular}




\section{DYSKUSJA}

Stosowanie glikokortykosteroidów u dzieci i młodzieży związane jest z występowaniem wielu powikłań narządowych, ogólnoustrojowych oraz zaburzeń metabolicznych [12].

W badaniu przeprowadzonym przez Banecką i wsp. wykazano, że stosowanie glikokortykosteroidów w dużym stopniu zwiększa poziom występowania zaburzeń węglowodanowych. Podczas występowania zaburzeń jedyną skuteczną i bezpieczną metodą leczenia było podawanie preparatów insuliny oraz stosowanie diety cukrzycowej [13].

W badaniach własnych w przypadku zbyt wysokich poziomów glikemii większość pacjentów stosowało ograniczenia spożywania pokarmów i dodatkowy ruch.

Patogeneza cukrzycy u dzieci z ALL w czasie leczenia onkologicznego poddawanych sterydoterapii i chemioterapii jest złożona. Zmniejszenie produkcji insuliny, zmniejszenie ekspresji receptorów insulinowych, mniejsze powinowactwo insuliny do receptorów insulinowych (insulinooporność) mogą być spowodowane przez stosowanie preparatów asparaginazy i kortykosteroidów podczas leczenia [14].

Lowas i wsp. w swoim badaniu zauważyli zaburzenia gospodarki węglowodanowej, które dodatkowo były spowodowane przez stosowaną w protokołach leczniczych asparaginazę. Aż $20 \%$ badanych miała stwierdzoną przejściową hiperglikemię [15].

W badaniu przeprowadzonym przez Aisyi i wsp. tylko $5,2 \%$ badanych miało stwierdzoną hiperglikemię spowodowaną przez deksametazon w połączeniu z L-asparaginazą [16].

W przeprowadzonym przez autorów badaniu wyłącznie u $1 / 36$ dziecka poziom glikemii wynosił poniżej 70 $\mathrm{mg} \%$, stężenia glukozy powyżej $180 \mathrm{mg} \%$ stwierdzono tylko u 4/36 dzieci. U pozostałych dzieci poziomy glikemii były prawidłowe. Wyniki te moga wiązać się z tym, że $80,6 \%$ ankietowanych podało, że przestrzega diety u swoich dzieci.

Otyłość jest częstym problemem zdrowotnym u dzieci z ALL i jest wynikiem nadmiernego spożycia energii i zmniejszonego wydatku energetycznego [17].

W badaniu Esbenshade i wsp. oraz Jansen i wsp. odnotowano występowanie otyłości i nadciśnienia tętniczego u dzieci z rozpoznaną ostrą białaczką limfoblastyczną podczas leczenia $\mathrm{z}$ wykorzystaniem glikokortykosteroidów $[8,17]$.

Van Dongen-Melman'a i wsp. w swoich badaniach stwierdzili, że otyłość u dzieci z ALL jest późnym efektem ubocznym leczenia. Wykazali, że największy wpływ na przyrost masy ciała u dzieci z białaczką ma stosowanie glikokortykosteroidów [18].

Iughetii i wsp. wykazali, że u większości młodych osób, które były leczone $z$ powodu ALL, występuje nadmierny przyrost masy ciała, otyłość centralna, dyslipidemia i zespół metaboliczny [19].

Veringa i wsp. w swoich badaniach wykazali, że otyłość lub nadwaga występuje u 38,2\% osób, które przeżyły ALL. Stan przedciśnieniowy rozpoznano u $48,5 \%$ badanych, natomiast nadciśnienie tętnicze u 22,1\% [20].
W naszych badaniach u 13/36 dzieci z ALL stwierdzono prawidłowe ciśnienie tętnicze krwi, u 15/36 nadciśnienie tętnicze 1 . stopnia, zaś u 6/36 dzieci zaobserwowano nadciśnienie tętnicze 2. stopnia. Natomiast prawidłową masę ciała stwierdzono u 22/36 dzieci, niedowagę $u$ 3/36, nadwagę u 2/36, a otyłość u 8/36 dzieci.

Dieta oraz aktywność fizyczna jest jednym z niewielu modyfikowalnych zachowań, które mogą zapobiec lub opóźnić wystąpienie chorób przewlekłych związanych z otyłością. Aktywność fizyczna u dzieci z ALL poprawia sprawność fizyczną i metaboliczną, zmniejsza ryzyko wystąpienia upośledzenia fizycznego oraz poprawia jakość życia [21].

Reilly'a i wsp. oraz Alias i wsp. zaobserwowali zmniejszoną aktywność fizyczną u dzieci z ALL. Dzieci z ALL znacznie rzadziej wykonują aktywność fizyczną niż ich zdrowi rówieśnicy, zarówno podczas, jak i po terapii [6,22]. Dzieci, które zakończyły leczenie z powodu białaczki, powinny regularnie wykonywać aktywność fizyczną dostosowaną do ich wydolności krążeniowo-oddechowej i mięśniowej [21].

Dzieci chore na nowotwory są bardziej narażone na niedożywienie i nadmierny przyrost masy ciała podczas leczenia [23]. Stosowanie kortykosteroidów może prowadzić do większego spożycia produktów wysokoenergetycznych $[6,17]$.

Li i wsp. wykazali, że dzieci, które przeżyły leczenie z powodu ALL, spożywały produkty wysokoenergetyczne, ubogie w mikroelementy. Dodatkowo prednizon oraz deksametazon zwiększają apetyt na żywność o wysokiej zawartości węglowodanów i soli. Dlatego zastosowanie zasad racjonalnego żywienia podczas leczenia może zmniejszyć przyrost masy ciała [5].

W naszych badaniach pacjenci mieli zwiększone łaknienie podczas leczenia glikokortykosteroidami, natomiast nie zaobserwowano większego spożycia niedozwolonych w diecie: słodyczy i „fast foodów” oraz pieczywa białego.

Ponadto leczenie glikokortykosteroidami jest dodatkowym czynnikiem ryzyka zakażeń bakteryjnych i grzybiczych u pacjentów onkologicznych.

Badania przeprowadzone przez Sonabend i wsp wykazały związek pomiędzy występowaniem przejściowej hiperglikemii u dzieci leczonych z powodu ostrej białaczki limfoblastycznej, a zwiększonym ryzykiem występowania bakteriemii i koniecznych dodatkowych hospitalizacji. U pacjentów, u których występowała łagodna hiperglikemia, 140-199 mg/dl, oraz hiperglikemia powyżej $200 \mathrm{mg} /$ dl w pierwszym roku leczenia, zaobserwowano 4,2 raza częstsze występowanie infekcji bakteryjnych lub grzybiczych w porównaniu do dzieci z prawidłowymi wartościami glikemii. Dzieci te były częściej dodatkowo hospitalizowane $\mathrm{z}$ powodu gorączki i neutropenii [24].

W badaniu O'Connor 35\% dzieci z ALL cierpiało $\mathrm{z}$ powodu infekcji dróg oddechowych, $11 \% \mathrm{z}$ powodu infekcji żołądkowo-jelitowych oraz $11 \% \mathrm{z}$ powodu infekcji ośrodkowego układu nerwowego [25].

Podobne wyniki uzyskał Weiser i wsp. Pacjenci z hiperglikemią podczas chemioterapii indukcyjnej z powodu ALL, są bardziej narażeni na zakażenia i doświadczają znacznego wzrostu ogólnej śmiertelności oraz ryzyka 
nawrotu choroby w porównaniu $\mathrm{z}$ pacjentami bez objawów hiperglikemii [26].

Biorąc pod uwagę, że styl życia jest modyfikowalnym czynnikiem, konieczne wydaje się promowanie zdrowego stylu życia u pacjentów z ALL i u ich rodzin. Należy zwrócić uwagę na edukację zdrowotną prowadzoną podczas leczenia oraz również po jego zakończeniu, aby zminimalizować ryzyko rozwoju otyłości u dzieci i dorosłych, którzy przeszli leczenie onkologiczne w dzieciństwie oraz problemów zdrowotnych z niej wynikających.

\section{WNIOSKI}

1. Prawidłowa masa ciała występuje u większości dzieci z ALL podczas sterydoterapii.

2. Dzieci z ALL podczas sterydoterapii są obciążone nadciśnieniem tętniczym.

3. Większość rodziców lub opiekunów prawnych dzieci i młodzieży z ALL stosowała się do zaleceń dietetycznych podczas sterydoterapii.

\section{ORCID}

Anna Stefanowicz-Bielska (iD https://orcid.org/0000-0002-1896-5551 Marta Hadaś (iD https://orcid.org/0000-0001-5220-5313

\section{REFERENCES/PIŚMIENNICTWO}

1. Pegon Ch, Rochette E, Rouel N, et al. Childhood Leukemia Survivors and Metabolic Response to Exercise: A Pilot Controlled Study, J Clin Med. 2020;9(2):562, D0I: 10.3390/jcm9020562

2. Derwich K, Zając-Spychała 0. Zaburzenia genetyczne w ostrej białaczce limfoblastycznej u dzieci i ich wykorzystanie w praktyce klinicznej. Hematologia. 2012;3(3):221-230

3. Mały E, Przyborska M, Derwich K, et al. Zmiany cytogenetyczne a pozostałe czynniki prognostyczne u dzieciz ostrą białaczką limfoblastyczną - badania jednoośrodkowe. Acta Haematologica Polonica. 2011;42(3): 507-512.

4. Bulas M, Pierlejewski F, Młynarski W. Glikokortykosteroidooporność w chorobach limfoproliferacyjnych u dzieci. Przegląd pediatryczny. 2009;39(1):57-61.

5. Li R, Donnella $H$, Knouse $P$, et al. A randomized nutrition counseling intervention in pediatric leukemia patients receiving steroids results in reduced caloric intake. Pediatr Blood Cancer. 2017;64:374-380. D0I: 10.1002/pbc.26231

6. Reilly JJ, Brougham M, Montgomery C, et al. Effect of Glucocorticoid Therapy on Energy Intake in Children Treated for Acute Lymphoblastic Leukemia. The Journal of Clinical Endocrinology \& Metabolism. 2001;86(8):3742-3745. D0l: 10.1210/ jcem.86.8.7764

7. Marchewka Z, Guzy K, Robach-Dolata A, et al. Leki jako czynniki ryzyka rozwoju hiperglikemii oraz mechanizmy ich działania diabetogennego. Farm Pol. 2017;73(2): 105-114.

8. Esbenshade AJ, Simmons JH, Koyama T, et al. Body mass index and blood pressure changes over the course of treatment of pediatric acute lymphoblastic leukemia. Pediatr Blood Cancer. 2011;56:372-378. D0I: 10.1002/pbc.22782

9. Kułaga Z, Różdżyńska-Świątkowska A, Grajda A, et al. Siatki centylowe dla oceny wzrastania i stanu odżywienia polskich dzieci i młodzieży od urodzenia do 18 roku życia. Standardy Medyczne. Pediatria. 2015;12:119-135.

10. www.cdc.gov/growthcharts, accessed on: 04.07 .2020

11. Flynn JT, Kaelber DC, Baker-Smith CM, et al. Clinical Practice Guideline for Screening and Management of High Blood Pressure in Children and Adolescents. Pediatrics 2017;140(3): e20171904. D0I: 10.1542/peds.2017-1904

12. Pisarczyk-Wiza D, Zozulińska-Ziółkiewicz D. Glikokortykosteroidy a zaburzenia metabolizmu glukozy. Diabetologia Kliniczna. 2015;4(3): 110-116.

13. Banecka B, Lesiuk M, Beń-Skowronek I, et al. Przejściowe zaburzenia gospodarki węglowodanowej w czasie intensywnego leczenia ostrej białaczki limfoblastycznej u dzieci. Endokrynologia Pediatryczna. 2013;3 (44): 47-52.

14. Hijiya $\mathrm{N}$, van der Sluis I. Asparaginase-associated toxicity in children with acute lymphoblastic leukemia, Leukemia \& Lymphoma. 2016;57(4):748-757. D0l: 10.3109/10428194.2015.1101098
15. Lowas SR, Marks D, Malempati S. Prevalence of transient hyperglycemia during induction chemotherapy for pediatric acute lymphoblastic leukemia. Pediatr Blood Cancer. 2009;52: 814-818. D0I 10.1002/pbc.21980

16. Aisyi M, Andriastuti M, Kurniati N. The Effect of Combination of Steroid and L-Asparaginase on Hyperglycemia in Children with Acute Lymphoblastic Leukemia (ALL), Asian Pac J Cancer Prev. 2019;1;20(9):2619-2624. D0l: 10.31557/ APJCP.2019.20.9.2619

17. Jansen H, Postma A, Stolk RP, Kamps WA. Acute lymphoblastic leukemia and obesity: increased energy intake or decreased physical activity? Support Care Cancer. 2009;17(1):103-106. DOI: 10.1007/s00520-008-0531-0

18. Van Dongen-Melman JEWM, Hokken-Koelega ACS, Hählen K, et al. Obesity after successful treatment of acute lymphoblastic leukemia in childhood. Pediatric Research 1995;38 (1): 86-90. D0I: 10.1203/00006450-199507000-00015

19. lughetti L, Bruzzi P, Predieri B, et al. Obesity in patients with acute lymphoblastic leukemia in childhood. Italian Journal of Pediatrics. 2012;38 (4):2-11.

20. Veringa SJE, van Dulmen - den Broeder E, Gertjan JL Kaspersky GJL, et al. Blood pressure and body composition in long-term survivors of childhood acute lymphoblastic leukemia, Pediatr Blood Cancer 2012;58: 278-282, D0l: 0.1002/ pbc.23251

21. Pegon Ch, Rochette E, Rouel N, et al. Childhood Leukemia Survivors and Metabolic Response to Exercise: A Pilot Controlled Study, J Clin Med. 2020;9(2):562, DOl: $10.3390 / \mathrm{jcm} 9020562$

22. Alias H, Mohd Nazi NA, Lau Sie Chong D. Participation in Physical Activity and Physical Education in School Among Children With Acute Lymphoblastic Leukemia After Intensive Chemotherapy, Front Pediatr. 2019;7: 73. D0I: 10.3389/fped.2019.00073

23. Beaulieu-Gagnon S, Bélanger V, Meloche C. Nutrition education and cooking workshops for families of children with cancer: a feasibility study, BMC Nutr. 2019;19; 5:52. D0l: 10.1186/s40795-019-0319-2

24. Sonabend RY, McKay SV, Oncu MF, et al. Hyperglycemia during induction therapy is associated with increased infectious complications in childhood acute lymphocytic leukemia. Pediatr Blood Cancer. 2008;51: 387-392. D0I 10.1002/pbc.21624

25. O'Connor D, Bate J, Wade R. Infection-related mortality in children with acute lymphoblastic leukemia: an analysis of infectious deaths on UKALL 2003, Blood. 2014;124(7):1056-1061. D0I: 10.1182/blood-2014-03-560847

26. Weiser MA, Cabanillas ME, Konopleva M i wsp. Relation between the duration of remission and hyperglycemia during induction chemotherapy for acute lymphocytic leukemia with a hyperfractionated cyclophosphamide, vincristine, doxorubicin, and dexamethasone/methotrexate-cytarabine regimen. Cancer. 2004;100 (6):11791185. D0l: $10.1002 /$ cncr.20071.

Manuscript received/Praca zgłoszona do czasopisma: 15.07.2020

Manuscript accepted/Praca zaakceptowana do druku: 04.09.2020

Translation/Tłumaczenie: Anna Sarad, EKO-BAU GRZEGORZ KLEIN ul. Osiedlowa 880-298 Gdańsk 